\title{
How shearwaters prey. New insights in foraging behaviour and marine foraging associations using bird-borne video cameras
}

\author{
Lucie Michel $^{1,2}$ (1) Marco Cianchetti-Benedetti ${ }^{2} \cdot$ Carlo Catoni $^{2} \cdot$ Giacomo Dell'Omo $^{2}$
}

Received: 17 June 2021 / Accepted: 9 November 2021

(c) The Author(s) 2021

\begin{abstract}
Conventional bio-logging techniques used for ethological studies of seabirds have their limitations when studying detailed behaviours at sea. This study uses animal-borne video cameras to reveal fine-scale behaviours, associations with conspecifics and other species and interactions with fishery vessels during foraging of a Mediterranean seabird. The study was conducted on Scopoli's shearwaters (Calonectris diomedea) breeding in Linosa island (35 51'33" N; 12 51'34" E) during summer 2020. Foraging events were video recorded from a seabirds' view with lightweight cameras attached to the birds' back. Foraging always occurred in association with other shearwaters. Competitive events between shearwaters were observed, and their frequency was positively correlated to the number of birds in the foraging aggregation. Associations with tunas and sea turtles have been frequent observations at natural foraging sites. During foraging events, video recordings allowed observations of fine-scale behaviours, which would have remained unnoticed with conventional tracking devices. Foraging events could be categorised by prey type into "natural prey" and "fishery discards". Analysis of the video footage suggests behavioural differences between the two prey type categories. Those differences suggest that the foraging effort between natural prey and fishery discards consumption can vary, which adds new arguments to the discussion about energy trade-offs and choice of foraging strategy. These observations highlight the importance of combining tracking technologies to obtain a complete picture of the at-sea behaviours of seabirds, which is essential for understanding the impact of foraging strategies and seabird-fishery interactions.
\end{abstract}

Keywords At-sea behaviour $\cdot$ Marine associations $\cdot$ Animal-borne video cameras $\cdot$ Foraging ecology $\cdot$ Seabird-fishery interactions

\section{Introduction}

Understanding patterns in seabirds' foraging behaviour can help identify critical factors for successful foraging, breeding and life-history traits (Davoren et al. 2003; Weimerskirch 2007) in marine habitats. So does understanding the role of social interactions (Jones et al. 2018). Observations of foraging behaviours can give information about preferred prey type (Elliott et al. 2008) and accessibility limitations such

Responsible Editor: V. Paiva.

Lucie Michel

lucie.michel@bio.uni-giessen.de

1 Department of Animal Ecology and Systematics, Justus Liebig University Giessen, Heinrich-Buff-Ring 26, 35392 Giessen, Germany

2 Ornis Italica, Piazza Crati 15, 00199 Rome, Italy as depth (Burger 2001) and are relevant for evaluating the costs and benefits of foraging because behavioural factors like flapping, landing, and take-off can influence foraging effort (Shaffer et al. 2001). Furthermore, it is crucial to comprehend the natural foraging ecology of seabirds to describe the impact of human activities such as exploitation by fisheries on marine ecosystems (Furness et al. 2007; Lescroël et al. 2016; Le Bot et al. 2018).

Scopoli's shearwaters (Calonectris diomedea) are known to be flexible foragers that forage mainly at the sea surface (Zootier et al. 1999; Cianchetti-Benedetti et al. 2017). They cover vast areas of the open sea on the search for prey, but little is known about how these shearwaters locate prey, forage and how they associate with conspecifics or other species. Previous studies found that Scopoli's shearwaters interact with fishing vessels (Cecere et al. 2015; CianchettiBenedetti et al. 2018; Karris et al. 2018), but their behaviour in the vicinity of fishing vessels or consuming discards 
has rarely been described in detail. Costs and benefits of foraging strategies can vary according to the circumstances encountered (e.g., level of intraspecific competition (Lewis et al. 2001), type of prey consumed (van Donk et al. 2019). On the one hand, consumption of discards can be disadvantageous and lead to reduced reproductive success if the energy spent on consuming discards cannot be compensated by the nutritional quality of the discarded food source and natural stocks are depleted (Grémillet et al. 2008; Le Bot et al. 2019). On the other hand, discards can represent an important food source as they provide seabirds with resources (benthic or large fish) that cannot be obtained in different ways (Furness 2003). However, interactions with fisheries can be fatal for seabirds because of the risk of bycatching related to fishing gear like hooks from long-line fishing and nets from gillnetting (Karris et al. 2013; Dimech et al. 2009; Cortés et al. 2018). This study aimed to observe foraging associations and fine-scale foraging behaviours of a Mediterranean seabird using bird-borne video cameras and see how they vary according to prey type.

Remote sensing techniques have gained importance for seabirds' behavioural research and comprise a refined and sophisticated set of technologies (Wilson et al. 2002; RopertCoudert 2005; Yoda et al. 2019), but fine-scale behaviours during foraging and circumstances that can influence the behaviours are difficult to identify and verify. Bird-borne video cameras allow direct observations, snapshots from the seabird's life, revealing new and unexpected behaviours. So far, this technique was used for land (Bluff and Rutz 2008; Rutz and Troscianko 2013) and marine birds (Takahashi et al. 2004; Watanuki et al. 2008; Sakamoto et al. 2009; Grémillet et al. 2010; Votier et al. 2013; Tremblay et al. 2014) but rarely for small-medium sized seabirds (Yoda 2019) due to the weight constriction and battery duration of video cameras.

The study site, Linosa island, located in the Sicily Channel in the central Mediterranean Sea, is important for demersal fisheries (Russo et al. 2014) and small artisanal fisheries (Lleonart and Maynou 2003; Kelleher 2005). The Scopoli's shearwater is a colonial breeding burrow-nester that raises a single chick per breeding season. Partners share their parental duties. After chick hatching in mid-July, adults forage close to the colony and return to feed their chick at night frequently (Cianchetti-Benedetti et al. 2017). Its natural diet includes a wide range of medium to small-sized fish, squid, and eventually zooplankton (Grémillet et al. 2014). Fishery discards are suggested to be part of its diet as well (Cianchetti-Benedetti et al. 2018; Karris et al. 2018; Cecere et al. 2015). The recorded video material of this study provides exclusive insights into the at-sea behaviour of Mediterranean shearwaters, first-time proof of foraging associations with sea turtles, and firsthand evidence for discard consumption and seabird-fishery interactions.

\section{Methods}

\section{Data collection}

The study was carried out in the colony of Scopoli's shearwaters of Linosa island ( $35^{\circ} 51^{\prime} 33^{\prime \prime} \mathrm{N} ; 12^{\circ} 51^{\prime} 34^{\prime \prime}$ E) during the breeding season 2020. Linosa hosts one of the biggest European colonies of Scopoli's shearwaters with 10,000 estimated couples (Baccetti et al. 2009). Seven birds were equipped with miniaturised video cameras (Technosmart Europe S.r.l., Rome, IT) during the early chick-rearing period (20th July to 10th August 2020). The cameras with a resolution of $720 \mathrm{P}$ weighed $21 \mathrm{~g}$ and recorded continuously for $5 \mathrm{~h}$ approximately. They were set to start recording at $12 \mathrm{AM}$ (local time) to cover the peak times of foraging activity (Cianchetti-Benedetti et al. 2017). Only birds weighing more than $710 \mathrm{~g}$ (i.e., males) were selected to ensure that the device did not exceed $3 \%$ of the bodyweight of birds. Camera deployment occurred at night when the birds visited the colony. Birds were captured in their nest, and the camera was attached to the back feathers using marine waterproof Tesa ${ }^{\circledR}$ tape (Wilson and Wilson 1989). The attachment position ensured a frontal view of a $45^{\circ}$ angle which included the bird's head. The deployment procedures did not take longer than $5 \mathrm{~min}$, and the bird was released inside the nest afterwards. In six out of seven cases, the birds were recaptured in the night following the first capture. Indeed, during this phase, the shearwaters in Linosa perform mainly one-day foraging trips (Cianchetti-Benedetti et al. 2017). In one case, the camera was recovered after seven days because the bird probably completed a long foraging trip. None of the selected birds deserted the nest after the camera deployment, and their chicks fledged successfully at the end of the breeding season.

\section{Data analysis}

Different behaviours related to foraging situations were identified by inspecting the video recordings: foraging events, competitive behaviour, and association with other species. Foraging events were defined as the approach and sojourn at a foraging assembly. Landing at a foraging site was considered the start of a foraging event (Video S1). When the bird moved away from the assembly (to perform other behaviours, like flying, preening, or sleeping), it was considered the end of the foraging event. Sequences of foraging events that were interrupted by flying off for more than 0.5 min or were interrupted by cleaning behaviour or resting for more than 1 min were counted as separate foraging events. To estimate the number of shearwaters 
present at the moment of the foraging attempt, a sequence of three aerial frames was taken right before landing on the foraging spot, and all birds in those frames were counted. The mean number of counted birds in the three shots was used to represent the number of birds that participated in the foraging bout and, therefore, competed for prey at the same moment. When other species were associated with the foraging events, these were, in general, fish or turtles. There were no other bird species. Unfortunately, it was not always possible to determine prey species in the pictures because of the low resolution of the video. A dive was defined when the bird immersed its body totally underwater, which was identified by underwater images (Fig. 1a) and Video S2). As the camera was attached to the dorsal feathers, video recordings provided reliable proof that the body was immersed in the water. A prey was considered "natural" when it was captured during feeding without anthropogenic influence (Video S2). In these cases, the prey was alive and actively swimming in small schools. Conversely, the prey was considered fishery discard when it could be identified as anthropogenic in origin. This was the case when fish was damaged or floating lifeless, scattered on or below the water surface (Fig. $1 \mathrm{~b}$ and Video S3) and when foraging occurred with a fishing vessel or gear insight.

Competitive events included all observations which originated from direct competition with other shearwaters (Fig. 1c, d). Bill fights, competition for the same fish, getting pushed out from the assembly, or having to fly off, were counted as competitive events. No direct competition with other species was observed.
The relationship between the number of competitive events and the number of birds associated with the foraging event was tested with a linear regression using a GLMM of the Poisson family (log-link) for count data. A random effect for bird ID was included to account for the multiple measurements of the same individuals. The model included the fixed effect "mean number of birds in feeding aggregation" as explanatory variables. The GLMM mentioned above was also used to test for behavioural differences (duration of foraging, number of dives performed, number of competitive events) between prey type categories "natural prey" and "fishery discards". Because of too few data points, the latter models did not converge when integrating a random factor to control for repeated measurements. For this reason, the data will be quantitatively described only. Model diagnostics were performed with the package DHARMa. All statistical analyses were run with $\mathrm{R}$ version 4.0.4 (R Core Team 2021).

\section{Results}

In total, $34 \mathrm{~h}(\min 2: 15, \max 5: 43$ per individual) of video material from seven birds were recorded. Individuals foraged on either natural prey or fishery discards but never both during the same foraging trip. Overall, 19 foraging events were filmed, of which three (16\%) were assigned to fishery discards, whereas $16(84 \%)$ occurred on natural prey (Table 1). At natural foraging sites, birds were often associated with loggerhead sea turtles (Carretta caretta) (Video S1 and S4) and bluefin-tunas (Thynnus thynnus) (Video S4). Within 16 natural foraging events, shearwaters
Fig. 1 a Diving shearwaters with the body completely immersed in the water. In front the head of the filming shearwater is visible b Discard foraging event, this fish is floating lifeless, vertical to the water surface. In the context of the video, more scattered fish carcasses are visible c Example of a competitive event; the filming bird gets attacked with the bill by conspecific at foraging event d Example of birds repositioning themselves at the centre of foraging activity by flying off and landing.
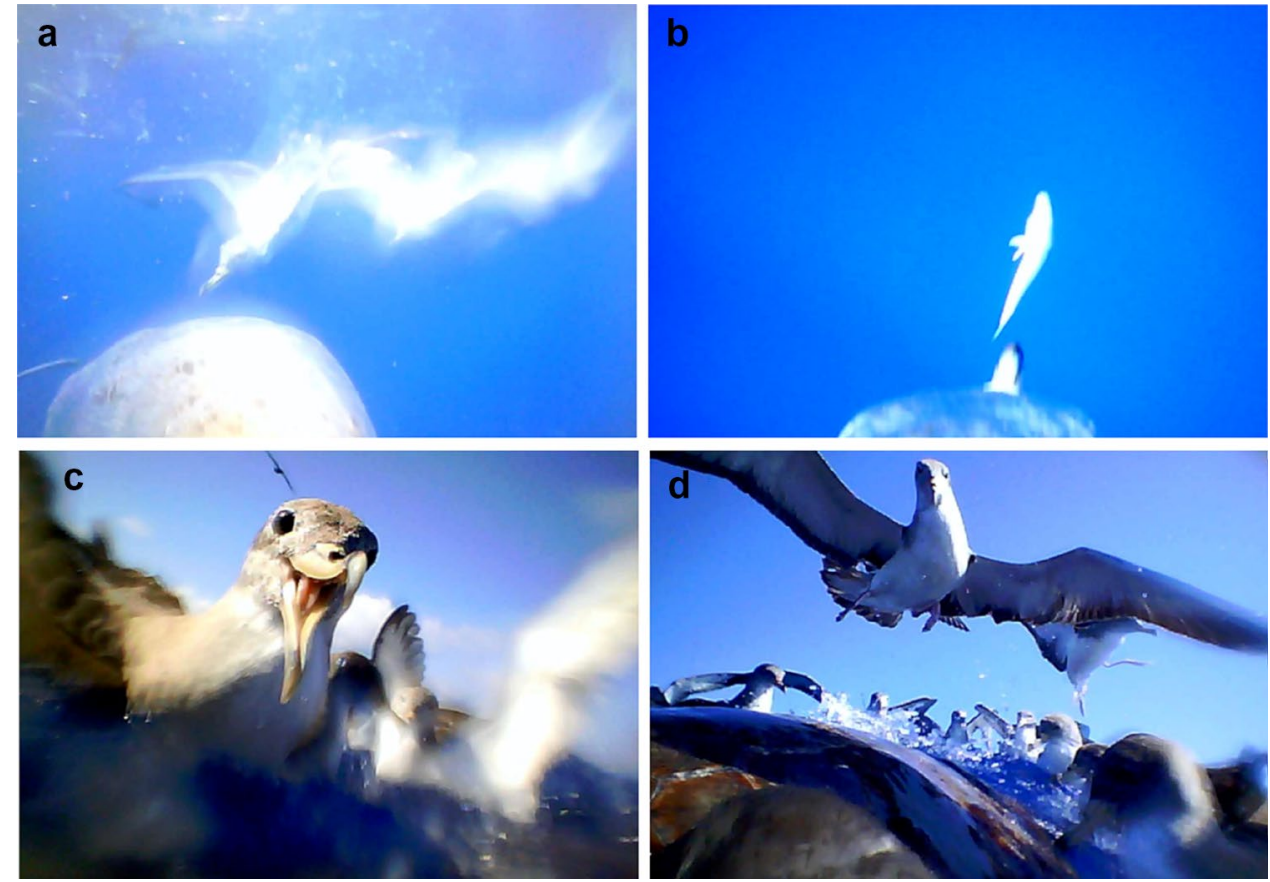
Table 1 This table compares the observed behaviours of individuals during foraging

\begin{tabular}{|c|c|c|c|c|c|c|c|c|}
\hline \multirow[t]{2}{*}{ Bird ID } & \multicolumn{2}{|l|}{ Dives } & \multicolumn{2}{|c|}{ Time at foraging site (S) } & \multicolumn{2}{|c|}{ Competitive events } & \multicolumn{2}{|c|}{$N$ foraging events } \\
\hline & Natural & Discards & Natural & Discards & Natural & Discards & Natural & Discards \\
\hline 1 & 23 & 0 & 990 & 0 & 8 & 0 & 3 & 0 \\
\hline 2 & 0 & 0 & 0 & 400 & 0 & 0 & 0 & 2 \\
\hline 3 & 24 & 0 & 1,110 & 0 & 5 & 0 & 2 & 0 \\
\hline 4 & 0 & 5 & 0 & 375 & 0 & 2 & 0 & 1 \\
\hline 5 & 7 & 0 & 678 & 0 & 8 & 0 & 3 & 0 \\
\hline 6 & 9 & 0 & 964 & 0 & 1 & 0 & 3 & 0 \\
\hline 7 & 26 & 0 & 443 & 0 & 11 & 0 & 5 & 0 \\
\hline$\Sigma$ & 89 & 5 & 4,185 & 775 & 33 & 2 & 16 & 3 \\
\hline MEAN (SD) & $12.7(10.6)$ & $0.7(1.7)$ & $597.9(430.2)$ & $110.7(175.2)$ & $5.5(3.9)$ & $0.3(0.7)$ & $2.3(1.7)$ & $0.4(0.7)$ \\
\hline
\end{tabular}

For each of the two prey type categories ("natural" referring to natural prey consumption and "discards" referring to the consumption of fishery discards), the number of dives, the time spent at the foraging sites in seconds, the number of observed competitive events and the total number of foraging events per animal are displayed. Totals are highlighted in bold, and means per bird with standard deviation in brackets are given at the bottom part of the table

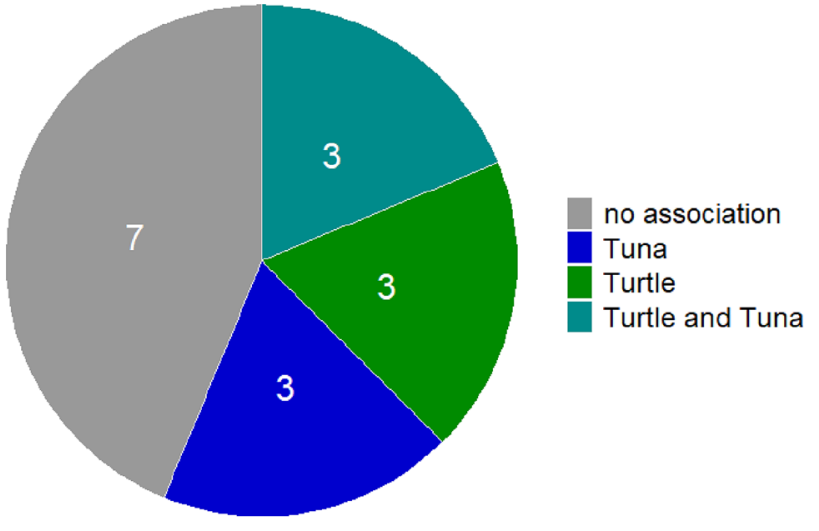

Fig. 2 Distribution of interspecific interactions during natural foraging events $(n=16)$

were associated with turtles in three events, with tunas in three events, and with both tunas and turtles in three other events (Fig. 2). At discard sites, no association with other animals was observed. Birds competed with their conspecifics at foraging sites (Fig. 1c, d). The number of competitive interactions was positively correlated to the number of birds in the aggregation at the moment of the foraging attempt (GLMM: $\chi^{2}=6.43$, p-value $=0.011$, $\left.\mathrm{R}^{2}(\mathrm{~m})=0.32, \mathrm{R}^{2}(\mathrm{c})=0.50\right)$. Variance in the random factor "bird ID" was Var $=0.27 \pm 0.52$ (Fig. 3). Interestingly, a tendency for differences in foraging strategy according to the type of prey was observed (Fig. 4). Shearwaters tended to spend more time foraging when preying on natural prey than on discards (Fig. 4a). Also, shearwaters that fed on natural prey tended to dive more frequently than those that fed on discards (Fig. 4b).

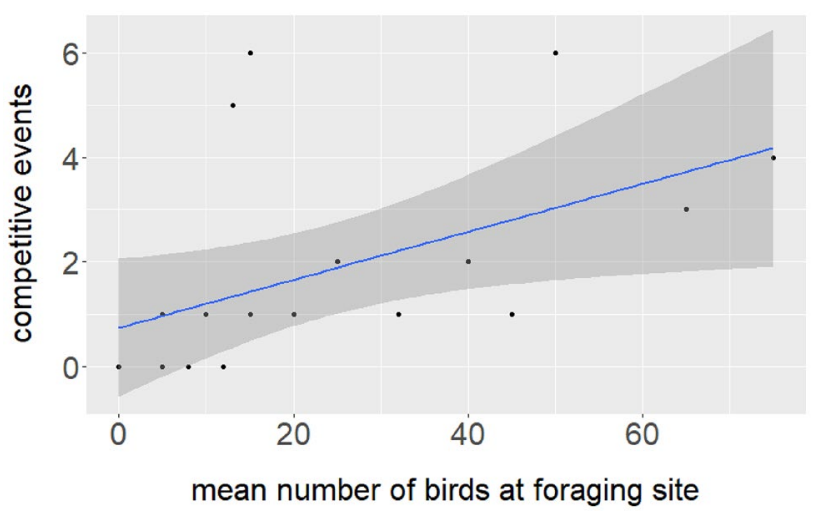

Fig. 3 Scatterplot showing a positive correlation between competitive events and the number of birds present at a foraging aggregation at the moment of foraging attempt $(n=19)$

\section{Discussion}

Our study revealed the at-sea behaviour of a medium-size seabird using miniaturised video cameras. To the best of the author's knowledge, this is the first time extended video recordings and complete foraging events, from prey location to active feeding, have been documented for Scopoli's shearwaters. Video recordings revealed fine-scale foraging behaviours, intra-, and interspecific associations, and point to differences in foraging effort depending on prey type consumed.

Consistent observations in Scopoli's shearwaters' foraging behaviour were that: (1) not a single bird foraged alone, without conspecifics in the vicinity, and (2) foraging events were diverse and always occurred opportunistically. These included feeding on discards with and without fishery 

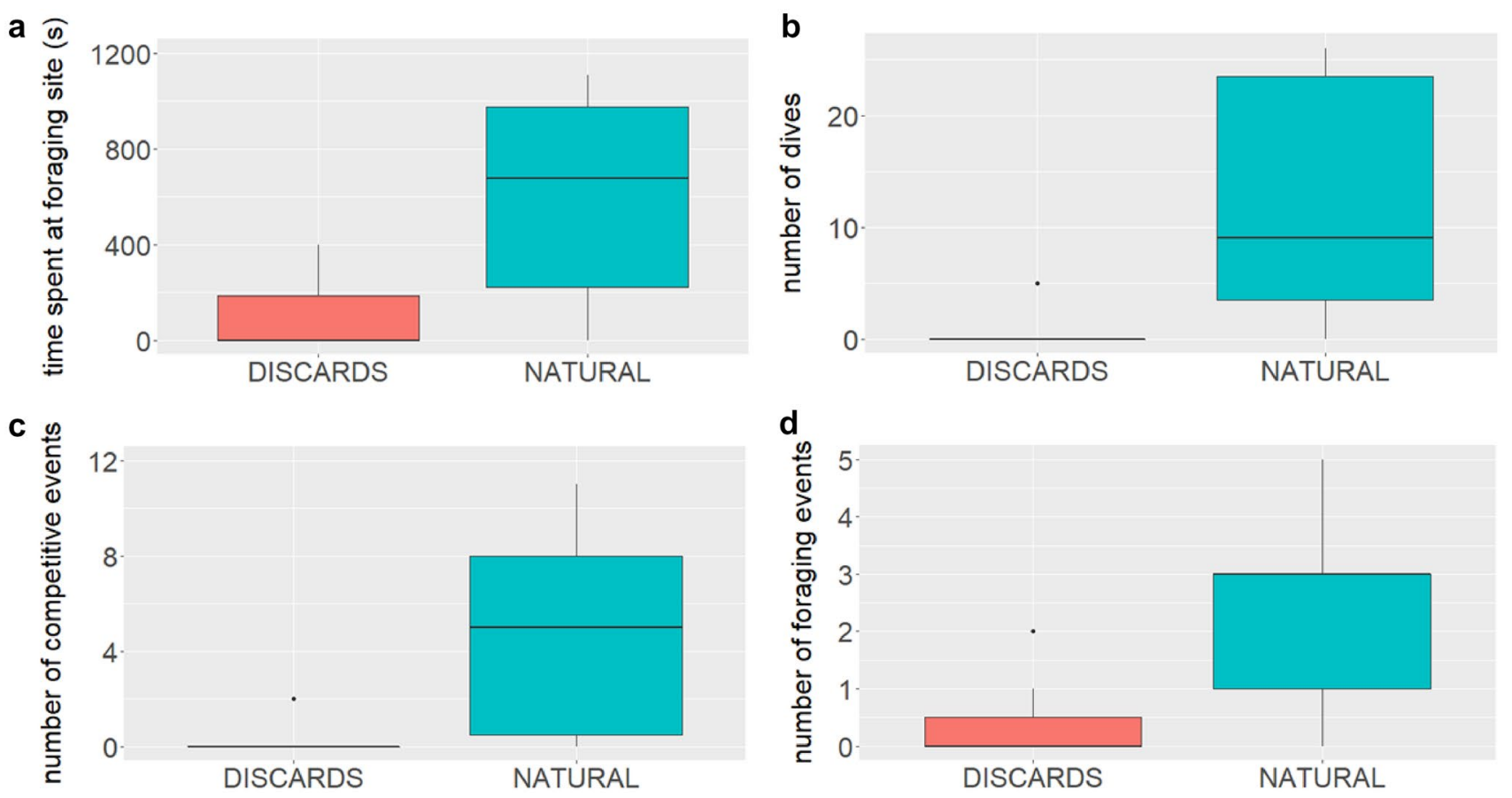

Fig. 4 Plots of a the duration spent at a foraging site in seconds $\mathbf{b}$ the number of dives observed $\mathbf{c}$ the number of competitive events observed $\mathbf{d}$ the number of foraging events assigned to each prey type

(natural prey and fishery discards). These boxplots visualise the data presented in Table 1

vessels in sight, feeding in association with hunting tunas, feeding in association with buoyant turtles. Feeding took place close to the surface, and shallow dives prevailed. Foraging events were observed more frequently with natural prey than with discards. This study collected data only on male shearwaters weighing $>700 \mathrm{~g}$ to ensure that the devices did not exceed $3 \%$ of the body weight. Therefore, no sex comparisons could be made.

\section{Competition}

Competitive events increased with the number of birds at foraging sites which could lower the chance of catching prey depending on its abundance. Competitive events tended to be more frequent at natural foraging sites (Fig. 4c). This resulted most likely from the circumstances at the natural foraging sites. There were well-defined aggregation cores where foraging activities were concentrated (Fig. 5 left, Video S1, S4). Here, shearwaters mainly sat on the water surface, dipping their head repeatedly into the water without immersing the whole body (Video S1). These head dips might have served to observe or catch prey right beneath them. Eventually, birds in the aggregation spread their wings to keep other individuals at a distance and defend their spot (Fig. 5 left). Repositioning by flying up and landing again at the centre of the foraging activity occurred repeatedly. While at discarding sites, preys were more scattered on and beneath

the water surface (Fig. 5 right), there was no defined core or centre of foraging activity and therefore less competition. Due to the fragmentary character of the videos, interpretations must be made with caution; there might have been temporal mismatches between the peak activity at a foraging site and when the equipped bird arrived there. It is also possible that bigger fishing vessels attract more birds resulting in higher competition at discarding. Other studies reported high competition around fishing vessels (Arcos et al. 2001; Karris et al. 2018).

\section{Foraging associations}

Shearwaters frequently foraged in association with other marine species like Bluefin tunas and Loggerhead turtles (Fig. 2). Marine predators benefit from these interactions because they increase their foraging success (Veit and Harrsion 2017). In the Mediterranean, the association of seabirds with subsurface predators seems to be a common phenomenon and previously has been reported for shearwaters (Arcos et al. 2008; Monteiro et al. 1996). Tunas that hunted from below and pushed fish into a dense ball formation close to the surface were observed (Fig. 5 bottom left). Although Audouin's gulls and terns have been associated with hunting tunas at Ebro delta (Oro 1995) and Northern gannets were almost always accompanied (93\% of cases) by other scavenging birds (Votier et al. 2013), no 


\section{Observation of differences between foraging on natural prey and fishery discards}

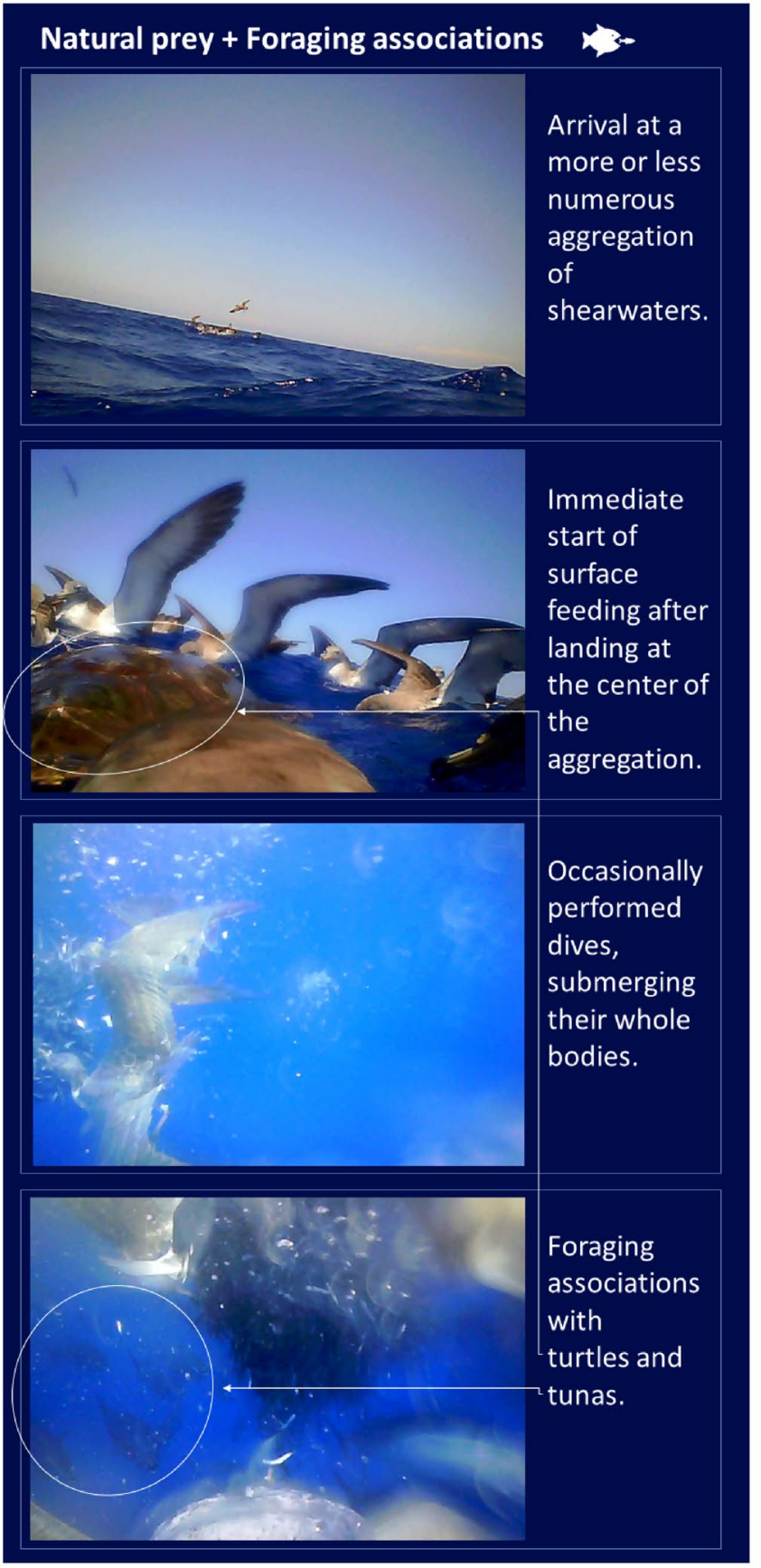

Fig. 5 Confrontation of the main observed differences during natural prey (left) and fishery discards (right) consumption supported by screenshots from the video material. Each picture highlights a distinctive feature of the respective foraging strategy and is shortly

other bird species has been observed in this study, which might be explained by the large distance to the coast or the relatively small size of the aggregations. However, it is possible that due to the restricted view of the camera,

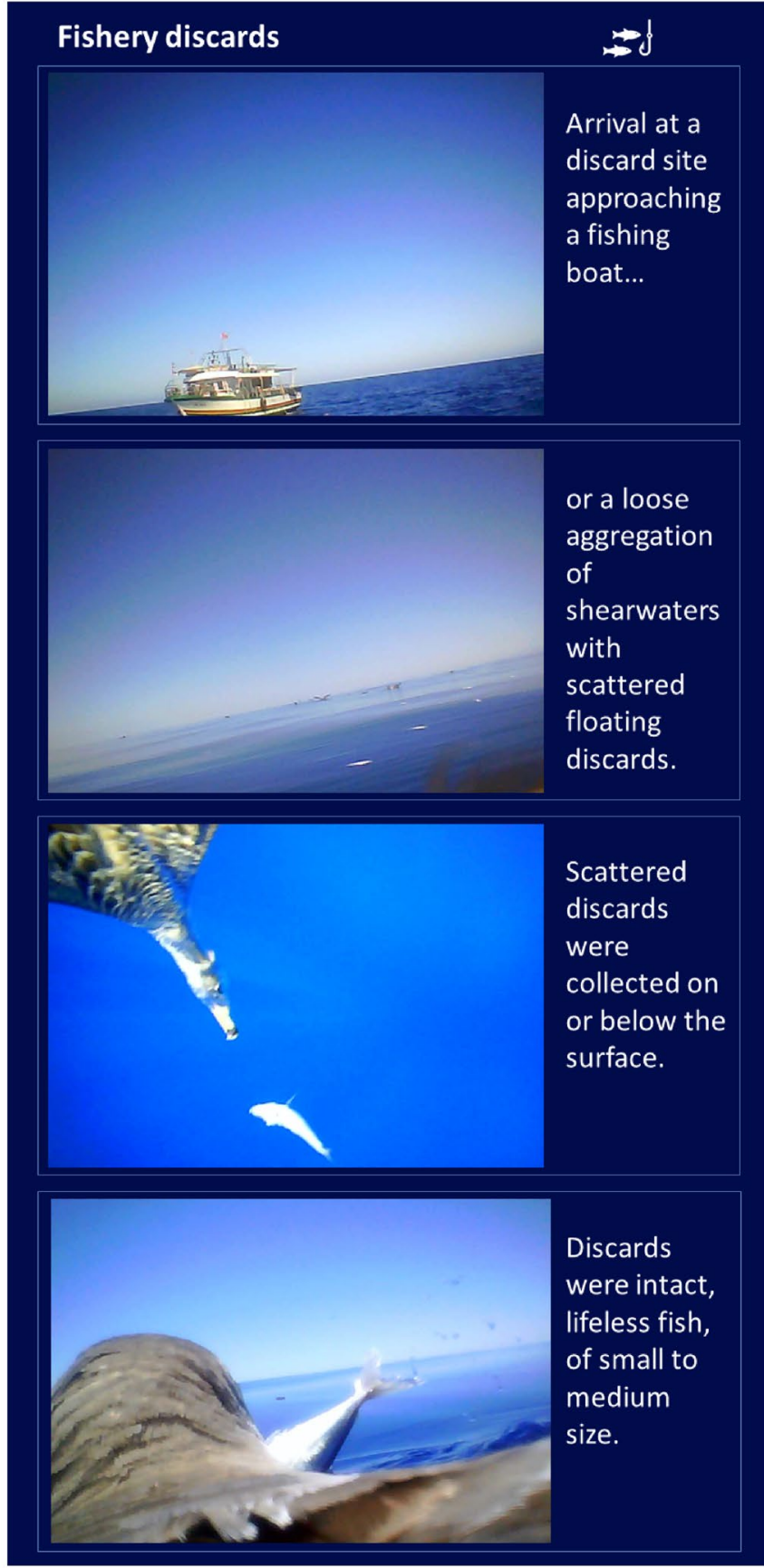

explained in the text next to it. Particularly addressed are differences during the approach at the foraging site, in foraging behaviours, prey, and foraging associations. Associated tunas and turtles are indicated with white arrows and circles

other species or associated tunas/turtles were present but not visible. 


\section{Locating foraging sites}

It has been suggested that seabirds locate prey in the vast pelagic environment by search patterns (Viswanathan et al. 1996) which can be influenced by spatial memory (Goyert 2015), olfactory (Nevitt and Bonadonna 2005) and visual stimuli (Martin and Prince 2001). These latter include search/recognition of fishing vessels or inter and intraspecific predator assemblies (Tremblay et al. 2014; Votier et al. 2013; Sakamoto et al. 2009). All foraging events in this study were preceded by approaching an aggregation of conspecifics. In no case, shearwaters foraged without conspecifics insight. Video recordings showed that birds flew for some time ( $30 \mathrm{~min}$ to $4 \mathrm{~h}$ ), likely searching for aggregations of conspecifics until they approached a spot with other foraging shearwaters.

\section{Floating turtles: a consistent observation}

Associations with turtles that are floating on the surface have been a consistent observation. There was evidence for a minimum of three turtles floating simultaneously on the water surface in proximity. Shearwaters assembled around them and fed on fish that aggregated below the turtles (Fig. 6, Video S4). It was not clear whether turtles attracted the fish like other buoyant objects in pelagic waters, if they preyed on the fish themselves or if they were injured and preyed upon. It has been reported that Balearic shearwaters fed on fish associated with buoyant objects (Arcos et al. 2000), but this is the first time that feeding associations with shearwaters and turtles have been described. Turtles are frequently injured by boats in the Italian waters, some get stranded, and others float (Casale et al. 2010). It was not clear from the video recordings whether turtles that were floating were injured or healthy, nor whether they were foraging.

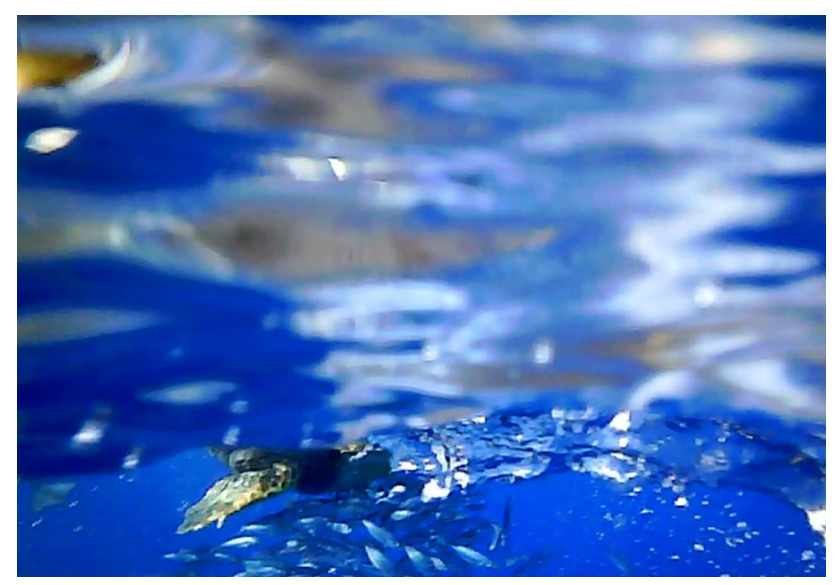

Fig. 6 Underwater view of $C$. caretta that is floating on the surface and fish aggregation underneath it
Loggerhead turtles are generalist and versatile predators of slow-moving or sessile prey (Tomas et al. 2001). Even though fish represented the most important prey of $C$. caretta in the western Mediterranean, the authors believe that this high rate of fish in the diet originated from discarded bycatch (Tomas et al. 2001). Observations by remotely operated vehicles in the Northwest Atlantic showed that Loggerhead turtles tended to remain within the near-surface and surface zones of the water column through much of the footage (Patel et al. 2016). However, they did not specify whether turtles were floating at the surface.

\section{Differences in prey type and foraging effort}

The here observed shearwaters feeding on natural prey tended to spend more time at the foraging sites, dive more, and engage in more competitive events than the birds feeding on fishery discards. Individual differences in foraging strategies within seabird populations have been described in previous studies (Votier et al. 2010; Patrick et al. 2015) and emerged in this study as well. Although the number of individuals studied here was low, this was reflected by individuals feeding either on natural prey or on fishery discards but in no case on both of them. These observed differences could be due to the individual preferences of the study subjects and are therefore not universally valid. There is evidence for personality influencing the foraging strategy of seabirds (Patrick and Weimerskirch et al. 2014).

Nevertheless, the video material documents constant distinct characteristics of the circumstances at the foraging site (Fig. 5), which likely cause the observed behavioural differences. The higher amount of time spent at natural foraging sites coupled with the higher frequency of dives indicate that feeding on natural prey can be more time and energy-demanding for shearwaters than feeding on discards. Still, natural prey consumption was more common than discard consumption in this study (Fig. 4d). It is possible that locating discarding sites would have involved longer search and coverage of larger distances, as reported by CianchettiBenedetti et al. 2018. These longer trips are avoided during the early chick-rearing period in which shearwaters usually perform short foraging trips close to the colony (CianchettiBenedetti et al. 2017; Paiva et al. 2010; Granadeiro et al. 1998; Magalhães et al. 2008). In this study, one-day trips prevailed, which might have had a strong influence on the foraging strategy.

Discard consumption has been suggested to be suboptimal for breeding gannets (Grémillet et al. 2008). Cape gannets (Morus capensis) that foraged on discards increased their foraging effort (Pichegru et al. 2007), and Northern gannets (Morus bassanus) had lower body condition (Le Bot et al. 2019). This occurred in populations breeding in areas with depleted fish stocks, and discards 
were mixed of offal and whole fish. By contrast, in the present study, all exploited discards represented an easy and energetically efficient prey, as they consisted of intact fish, which was collected within a shorter time and with less diving effort than natural prey (Fig. 4, Video S3). Factors like the availability of natural prey, the individual energetical demands according to the life-history stage, and the nutritional quality of fishery discards should be considered when discussing the benefits and costs of foraging strategies.

Seabird-fisheries interactions have been studied extensively for many species and marine habitats (Le Bot et al. 2018). In the Sicily Channel, about $40 \%$ of breeding Scopoli's shearwaters tagged with GPS interacted with fishery vessels (Cianchetti-Benedetti et al. 2018). A study that deployed cameras and GPS on Northern gannets reported a $42 \%$ association with fishing vessels (Votier et al. 2013). In the present study, ships were encountered in two cases representing $28 \%$ of the sampled birds, with foraging occurring only in one case. Additionally, one discard site was visited, but no vessel was in sight. There might have been a time shift here since the discards were discharged and when the shearwater arrived at the foraging site. These observations highlight the importance of combining technologies to detect foraging when studying seabird-fisheries interactions and quantify discard consumption. Additionally, GPS and accelerometer data can help to quantify energy effort invested into the respective foraging strategies. Paired with environmental data, they can be a powerful tool to study the impact of fishery overexploitation and discarding on seabirds.

\section{Dives}

Dive events in which their whole body was underwater were observed infrequently and mostly lasted fractions of seconds. Dives started from sitting on the surface or, less frequently, from plunging into the water from flight. Accordingly, a recent study found a high proportion of shallow and quick dives in Scopoli's shearwaters as 50\% of the dives occurred in the first $0.5 \mathrm{~m}$ of depth and $78 \%$ were less than $1 \mathrm{~m}$ deep and lasted $<2 \mathrm{~s}$ (CianchettiBenedetti et al. 2017). Shallow dives were recorded both during foraging at natural and discard sites. Although Scopoli's shearwaters can dive to 5-6 $\mathrm{m}$ or deeper (Cianchetti-Benedetti et al. 2017; Grémillet et al. 2014), the videos document that they extensively exploited food on or right beneath the water surface, which might make them less prone to access deeper and more agile prey and therefore, depend on foraging associations with predators that push the fish to the surface.

\section{Conclusions}

Video recordings allowed to observe fine-scale foraging behaviours that cannot be recorded with traditional tracking devices. They can verify if the prey was consumed at a foraging site and give an additional measure of energy expenses that have to be invested into successful foraging. Additionally, they allowed the observation of intra- and interspecific associations, which seem to play a significant role in successfully locating a foraging site and influence foraging success and energy expenses as well. The differences in fine-scale behaviours between natural prey and fishery discard consumption should be verified and considered in future studies investigating the impact of fishery activities on seabirds.

Although this study observed a low proportion of discard consumption compared to previous publications, concluding that they are an unimportant food source for these shearwaters would be inadequate. Assessing the impact of fisheries waste is not trivial, and it likely needs to be determined by a situation-based approach, as also suggested by Clark et al. (2020). It has been reported that there are great individual differences in foraging strategies within seabird populations (Patrick et al. 2015; Votier et al. 2010). Therefore, the importance of fishery discards consumption might vary on the individual level. Moreover, it can vary from year to year since fish stocks of the central Mediterranean are subject to fluctuations (Patti et al. 2004; Arcos et al. 2008). The discards observed in this study were intact. They implied low hunting effort, which could balance any energetical deficit from long searches, meaning that shearwaters might profit opportunistically from high-quality fishery discards, especially during the energy-demanding reproductive period in which they cover less area in search of prey. In this area of the Mediterranean, discards might be a less reliable food source since fishery fleets consist mainly of small artisanal boats, which produce small amounts of discards (Colloca et al. 2017; Tsagarakis et al. 2014), whose impact can vary in different situations.

In future research, bird-borne camera observations should be coupled with accelerometers and GPS. Supported with data about the position of the foraging sites and movement patterns at-sea behaviour, marine associations, and impact of fishery discards consumption on seabirds can be studied in greater detail. This knowledge can be valuable to determine comprehensive conservation measures.

Supplementary Information The online version contains supplementary material available at https://doi.org/10.1007/s00227-021-03994-w.

Acknowledgements We wish to thank Valeria Jennings for her valuable support, as well as Paolo Becciu and Sofia Bolumar Roda for their help with fieldwork. We thank the reviewers. 
Author contributions All authors contributed to the study's conception and design. LM and MC-B analysed the data. LM, MC-B and GDO carried out the fieldwork. LM drafted the manuscript, which was commented on by all co-authors. All authors read and approved the final manuscript. All authors gave final approval for publication.

Funding Open Access funding enabled and organized by Projekt DEAL. This project was carried out within a $\mathrm{PhD}$ project financed by DFG grant QU 148/23 to Professor Petra Quillfeldt from the University of Giessen. Technosmart Europe Srl provided the customised video cameras used in the study.

Availability of data and material The datasets used during the current study are available from the corresponding author on reasonable request.

Code availability Not applicable.

\section{Declarations}

Conflict of interest The authors have no conflicts of interest to declare that are relevant to the content of this article.

\section{Additional declarations for articles in life science journals that report the results of studies involving humans and/or animals Not applicable.}

Ethics approval All fieldwork was carried out according to the national legislation. The research was carried out with moral responsibility for the animals, with the final goal to preserve and enhance the future survival of that species and to provide knowledge vital to their conservation. No specimens were collected for this study. Birds were removed from their nest, weighed, and measured. Then, the logger was attached to the bird with tape, and it was returned to the nest burrows within 5 min of initial capture. The logger was recovered, and the tape was removed after 1 (in one case 7) days. We avoided any disturbance to the nest during the first days of the life of chicks. No nest desertion was observed due to our operations, and all chicks fledged successfully. The study was carried out under the permit n. 2452 issued the Regional authorities (Regione Siciliana, Assessorato Regionale dell'Agricoltura, dello Sviluppo Rurale e della Pesca Mediterranea, Dipartimento Regionale dello Sviluppo Rurale e Territoriale) on February 1st, 2018.

This research complies with the IUCN Policy Statement on Research Involving Species at Risk of Extinction (Scopoli's shearwater Calonectris diomedea is classified as "Least concern" in 2018).

Consent to participate. Not applicable.

Consent for publication. Not applicable.

Open Access This article is licensed under a Creative Commons Attribution 4.0 International License, which permits use, sharing, adaptation, distribution and reproduction in any medium or format, as long as you give appropriate credit to the original author(s) and the source, provide a link to the Creative Commons licence, and indicate if changes were made. The images or other third party material in this article are included in the article's Creative Commons licence, unless indicated otherwise in a credit line to the material. If material is not included in the article's Creative Commons licence and your intended use is not permitted by statutory regulation or exceeds the permitted use, you will need to obtain permission directly from the copyright holder. To view a copy of this licence, visit http://creativecommons.org/licenses/by/4.0/.

\section{References}

Arcos JM, Massutí E, Abelló P, Oro D (2000) Fish associated to floating drifting objects as a feeding resource for Balearic Shearwaters Puffinus mauretanicus during the breeding season. Ornis Fennica 77:177-182

Arcos J, Oro D, Sol D (2001) Competition between the yellow-legged gull Larus cachinnans and Audouin's gull Larus audouinii associated with commercial fishing vessels: the influence of season and fishing fleet. Mar Biol 139(5):807-816. https://doi. org/10.1007/s002270100651

Arcos JM, Louzao M, Oro D (2008) Fisheries ecosystem impacts and management in the Mediterranean: seabirds point of view. Am Fish Soc Symp 49(2):1471-1479

Baccetti N, Capizzi D, Corbi F, Massa B (2009) Breeding shearwaters on Italian islands: population size, island selection and co-existence with their main alien predator, the black rat. Riv Ital Orn 78:83-100

Bluff LA, Rutz C (2008) A quick guide to video-tracking birds. Biol Lett 4(4):319-322. https://doi.org/10.1098/rsbl.2008.0075

Burger AE (2001) Diving depths of shearwaters. Auk 118(3):755759. https://doi.org/10.1093/auk/118.3.755

Casale P, Affronte M, Insacco G, Freggi D, Vallini C, Pino d'Astore P, Argano R (2010) Sea turtle strandings reveal high anthropogenic mortality in Italian waters. Aquat Conserv Mar Freshwr Ecosyst 20(6):611-620. https://doi.org/10.1002/aqc.1133

Cecere JG, Catoni C, Gaibani G, Geraldes P, Celada C, Imperio S (2015) Commercial fisheries, inter-colony competition and sea depth affect foraging location of breeding Scopoli's Shearwaters Calonectris diomedea. Ibis 157:284-298. https://doi.org/ 10.1111/ibi.12235

Cianchetti-Benedetti M, Catoni C, Kato A, Massa B, Quillfeldt P (2017) A new algorithm for the identification of dives reveals the foraging ecology of a shallow-diving seabird using accelerometer data. Mar Biol 164(4):77. https://doi.org/10.1007/ s00227-017-3106-0

Cianchetti-Benedetti M, Dell'Omo G, Russo T, Catoni C, Quillfeldt $\mathrm{P}$ (2018) Interactions between commercial fishing vessels and a pelagic seabird in the southern Mediterranean Sea. BMC Ecol 18:1-10. https://doi.org/10.1186/s12898-018-0212-x

Clark BL, Vigfúsdóttir F, Jessopp MJ, Burgos JM, Bodey TW, Votier SC (2020) Gannets are not attracted to fishing vessels in Iceland-potential influence of a discard ban and food availability. ICES J Mar Sci 77(2):692-700. https://doi.org/10.1093/icesj $\mathrm{ms} / \mathrm{fsz} 233$

Colloca F, Scarcella G, Libralato S (2017) Recent trends and impacts of fisheries exploitation on Mediterranean stocks and ecosystems. Front Mar Sci 4:244. https://doi.org/10.3389/fmars.2017.00244

Cortés V, García-Barcelona S, González-Solís J (2018) Sex-and agebiased mortality of three shearwater species in longline fisheries of the Mediterranean. Mar Ecol Prog Ser 588:229-241. https:// doi.org/10.3354/meps1242

Davoren GK, Montevecchi WA, Anderson JT (2003) Search strategies of a pursuit-diving marine bird and the persistence of prey patches. Ecol Monogr 73(3):463-481. https://doi.org/10.1890/ 02-0208

Dimech M, Darmanin M, Caruana R, Raine H (2009) Preliminary data on seabird by-catch from the Maltese long line fishery (central Mediterranean). Collect Vol Sci Pap ICCAT 64(7):2335-2341

Elliott KH, Woo K, Gaston AJ, Benvenuti S, Dall'Antonia L, Davoren GK (2008) Seabird foraging behaviour indicates prey type. Mar Ecol Prog Ser 354:289-303. https://doi.org/10.3354/meps07221

Furness RW (2003) Impacts of fisheries on seabird communities. Sci Mar 67(S2):33-45. https://doi.org/10.3989/scimar.2003.67s233 
Furness R, Edwards A, Oro D (2007) Influence of management practices and of scavenging seabirds on availability of fisheries discards to benthic scavengers. Mar Ecol Prog Ser 350:235-244. https://doi.org/10.3354/meps07191

Goyert HF (2015) Foraging specificity and prey utilisation: evaluating social and memory-based strategies in seabirds. Behaviour 152(7-8):861-895. https://doi.org/10.1163/1568539X-00003260

Granadeiro JP, Nunes M, Silva MC, Furness RW (1998) Flexible foraging strategy of Cory's shearwater, Calonectris diomedea, during the chick-rearing period. Anim Behav 56(5):1169-1176. https:// doi.org/10.1006/anbe.1998.0827

Grémillet D, Pichegru L, Kuntz G, Woakes AG, Wilkinson S, Crawford RJ, Ryan PG (2008) A junk-food hypothesis for gannets feeding on fishery waste. Proc Rl Soc London Ser B 275(1639):11491156. https://doi.org/10.1098/rspb.2007.1763

Grémillet D, Mullers RH, Moseley C, Pichegru L, Coetzee JC, Sabarros PS, Ropert-Coudert Y (2010) Seabirds, fisheries, and cameras. Fron Ecol Environ 8(8):401-402. https://doi.org/10.1890/10.WB. 020

Grémillet D, Péron C, Pons JB, Ouni R, Authier M, Thévenet M, Fort J (2014) Irreplaceable area extends marine conservation hotspot off Tunisia: insights from GPS-tracking Scopoli's shearwaters from the largest seabird colony in the Mediterranean. Mar Biol 161(11):2669-2680. https://doi.org/10.1007/s00227-014-2538-z

Jones TB, Patrick SC, Arnould JP, Rodríguez-Malagón MA, Wells MR, Green JA (2018) Evidence of sociality in the timing and location of foraging in a colonial seabird. Biol Letters 14(7):20180214. https://doi.org/10.1098/rsbl.2018.0214

Karris G, Fric J, Kitsou Z, Kalfopoulou J, Giokas S, Sfenthourakis S, Poirazidis K (2013) Does by-catch pose a threat for the conservation of seabird populations in the southern Ionian Sea (eastern Mediterranean)? A questionnaire based survey of local fisheries. Mediterr Mar Sci 14(3):9-25. https://doi.org/10.12681/mms.541

Karris G, Ketsilis-Rinis V, Kalogeropoulou A, Xirouchakis S, Machias A, Maina I, Kavadas S (2018) The use of demersal trawling discards as a food source for two scavenging seabird species: a case study of an eastern Mediterranean oligotrophic marine ecosystem. Avian Res 9:26. https://doi.org/10.1186/s40657-018-0118-5

Kelleher K (2005) Discards in the world's marine fisheries: an update. FAO Fisheries Technical Paper No 470. ISBN:92-5-105289-1

Le Bot T, Lescroël A, Grémillet D (2018) A toolkit to study seabirdfishery interactions. ICES J Mar Sci 75(5):1513-1525. https://doi. org/10.1093/icesjms/fsy038

Le Bot T, Lescroël A, Fort J, Péron C, Gimenez O, Provost P, Gremillet D (2019) Fishery discards do not compensate natural prey shortage in Northern gannets from the English Channel. Biol Conserv 236:375-384. https://doi.org/10.1016/j.biocon.2019.05.040

Lescroël A, Mathevet R, Péron C, Authier M, Provost P, Takahashi A, Grémillet D (2016) Seeing the ocean through the eyes of seabirds: a new path for marine conservation? Mar Policy 68:212-220. https://doi.org/10.1016/j.marpol.2016.02.015

Lewis S, Sherratt TN, Hamer KC, Wanless S (2001) Evidence of intra-specific competition for food in a pelagic seabird. Nature 412(6849):816-819. https://doi.org/10.1038/35090566

Lleonart J, Maynou F (2003) Fish stock assessments in the Mediterranean: state of the art. Sci Mar 67(S1):37-49. https://doi.org/10. 3989/scimar.2003.67s137

Magalhães MC, Santos RS, Hamer KC (2008) Dual-foraging of Cory's shearwaters in the Azores: feeding locations, behaviour at sea and implications for food provisioning of chicks. Mar Ecol Prog Ser 359:283-293. https://doi.org/10.3354/meps07340

Martin GR, Prince PA (2001) Visual fields and foraging in procellariform seabirds: sensory aspects of dietary segregation. Brain Behav Evol. https://doi.org/10.1159/000047224

Monteiro LR, Ramos JA, Furness RW, Del Nevo AJ (1996) Movements, morphology, breeding, molt, diet and feeding of seabirds in the Azores. Colon Waterbirds 19(1):82-97. https://doi.org/10. $2307 / 1521810$

Nevitt GA, Bonadonna F (2005) Sensitivity to dimethyl sulphide suggests a mechanism for olfactory navigation by seabirds. Biol Lett 3:303-305. https://doi.org/10.1098/rsbl.2005.0350

Oro D (1995) Audouin's Gulls Larus audouinii associate with subsurface predators in the Mediterranean Sea. J Orn 136(4):465-467

Paiva VH, Geraldes P, Ramírez I, Meirinho A, Garthe S, Ramos JA (2010) Foraging plasticity in a pelagic seabird species along a marine productivity gradient. Mar Ecol Prog Ser 398:259-274. https://doi.org/10.3354/meps08319

Patel SH, Dodge KL, Haas HL, Smolowitz RJ (2016) Videography reveals in-water behavior of loggerhead turtles (Caretta caretta) at a foraging ground. Front Mar Sci 3:254. https://doi.org/10.3389/ fmars.2016.00254

Patrick SC, Weimerskirch H (2014) Personality, foraging and fitness consequences in a long lived seabird. PLoS One 9(2):e87269. https://doi.org/10.1371/journal.pone.0087269

Patrick SC, Bearhop S, Bodey TW, Grecian WJ, Hamer KC, Lee J, Votier SC (2015) Individual seabirds show consistent foraging strategies in response to predictable fisheries discards. J Avian Biol 46(5):431-440. https://doi.org/10.1111/jav.00660

Patti B, Bonanno A, Basilone G, Goncharov S, Mazzola S, Buscaino G, Cosimi G (2004) Interannual fluctuations in acoustic biomass estimates and in landings of small pelagic fish populations in relation to hydrology in the Strait of Sicily. Chem Ecol 20(5):365-375. https://doi.org/10.1080/027575404100017 27972

Pichegru L, Ryan PG, van der Lingen CD, Coetzee J, Ropert-Coudert Y, Grémillet D (2007) Foraging behaviour and energetics of Cape gannets Morus capensis feeding on live prey and fishery discards in the Benguela upwelling system. Mar Ecol Prog Ser 350:127136. https://doi.org/10.3354/meps07128

R Core Team (2021) R: a language and environment for statistical computing. R Foundation for Statistical Computing, Vienna. https:// www.R-project.org/

Ropert-Coudert Y, Wilson RP (2005) Trends and perspectives in animal-attached remote sensing. Front Ecol Environ 3(8):437-444. https://doi.org/10.1890/1540-9295(2005)003[0437:TAPIAR]2.0. $\mathrm{CO} ; 2$

Russo T, Parisi A, Garofalo G, Gristina M, Cataudella S, Fiorentino F (2014) SMART: a spatially explicit bio-economic model for assessing and managing demersal fisheries, with an application to Italian trawlers in the Strait of Sicily. PLoS One 9(1):e86222. https://doi.org/10.1371/journal.pone.0086222

Rutz C, Troscianko J (2013) Programmable, miniature video-loggers for deployment on wild birds and other wildlife. Methods Ecol Evol 4(2):114-122. https://doi.org/10.1111/2041-210x.12003

Sakamoto KQ, Takahashi A, Iwata T, Trathan PN (2009) From the eye of the albatrosses: a bird-borne camera shows an association between albatrosses and a killer whale in the Southern Ocean. PLoS One 4(10):e7322. https://doi.org/10.1371/journal.pone. 0007322

Shaffer SA, Costa DP, Weimerskirch H (2001) Behavioural factors affecting foraging effort of breeding wandering albatrosses. J Anim Ecol 70(5):864-874. https://doi.org/10.1046/j.0021-8790. 2001.00548.x

Takahashi A, Sato K, Naito Y, Dunn MJ, Trathan PN, Croxall JP (2004) Penguin-mounted cameras glimpse underwater group behaviour. Proc R Soc Lond Ser B 271(5):281-282. https://doi.org/10.1098/ rsbl.2004.0182

Tremblay Y, Thiebault A, Mullers R, Pistorius P (2014) Bird-borne video-cameras show that seabird movement patterns relate to previously unrevealed proximate environment, not prey. PLoS ONE 9(2):e88424. https://doi.org/10.1371/journal.pone.0088424 
Tsagarakis K, Palialexis A, Vassilopoulou V (2014) Mediterranean fishery discards: review of the existing knowledge. ICES J Mar Sci 71(5):1219-1234. https://doi.org/10.1093/icesjms/fst074

Van Donk S, Shamoun-Baranes J, Van Der Meer J, Camphuysen KC (2019) Foraging for high caloric anthropogenic prey is energetically costly. Mov Ecol 7(1):1-12. https://doi.org/10.1186/ s40462-019-0159-3

Veit RR, Harrison NM (2017) Positive interactions among foraging seabirds, marine mammals and fishes and implication for their conservation. Front Ecol Evol 5:121. https://doi.org/10.3389/fevo. 2017.00121

Viswanathan G, Afanasyev V, Buldyrev S et al (1996) Lévy flight search patterns of wandering albatrosses. Nature 381:413-415. https://doi.org/10.1038/381413a0

Votier SC, Bearhop S, Witt MJ, Inger R, Thompson D, Newton J (2010) Individual responses of seabirds to commercial fisheries revealed using GPS tracking, stable isotopes and vessel monitoring systems. J Appl Ecol 47(2):487-497. https://doi.org/10.1111/j. 1365-2664.2010.01790.x

Votier SC, Bicknell A, Cox SL, Scales KL, Patrick SC (2013) A bird's eye view of discard reforms: bird-borne cameras reveal seabird/ fishery interactions. PLoS ONE 8(3):e57376. https://doi.org/10. 1371/journal.pone.0057376

Watanuki Y, Daunt F, Takahashi A, Newell M, Wanless S, Sato K, Miyazaki N (2008) Microhabitat use and prey capture of a bottom-feeding top predator, the European shag, shown by camera loggers. Mar Ecol Prog Ser 356:283-293. https://doi.org/10. 3354/meps07266

Weimerskirch H (2007) Are seabirds foraging for unpredictable resources? Deep Sea Res Part II Top Stud Oceanogr 54(3-4):211223. https://doi.org/10.1016/j.dsr2.2006.11.013

Wilson RP, Wilson M-PTJ (1989) Tape: a package attachment technique for penguins. Wildl Soc Bull 17:77-79

Wilson RP, Grémillet D, Syder J, Kierspel MA, Garthe S, Weimerskirch H, Nel D (2002) Remote-sensing systems and seabirds: their use, abuse, and potential for measuring marine environmental variables. Mar Ecol Prog Ser 228:241-261. https://doi.org/10. $3354 /$ meps 228241

Yoda K (2019) Advances in bio-logging techniques and their application to study navigation in wild seabirds. Adv Rob 33(3-4):108 117. https://doi.org/10.1080/01691864.2018.1553686

Zotier R, Bretagnolle V, Thibault JC (1999) Biogeography of the marine birds of a confined sea, the Mediterranean. J Biogeogr 26(2):297-313. https://doi.org/10.1046/j.1365-2699.1999.00260.x

Publisher's Note Springer Nature remains neutral with regard to jurisdictional claims in published maps and institutional affiliations. 